\title{
DOI: https://doi.org/10.24297/jssr.v14i0.8111
}

\section{Political Dimensions of Weaker Sections Welfare in Local Self Government in India: A Study}

\author{
V. Rama Krishna* \& Dr. Uddagatti Venkatesha** \\ *Assistant Professor, Department of Studies and Research in Political Science, Tumkur University, Tumakuru- \\ 572103. \\ ** Associate Professor, Department of Studies and Research in political Science, Kuvempu University, \\ Shankaragatta - 5774 51, Karnataka State. \\ rahul_rk2004@yahoo.co.in
}

\begin{abstract}
Soon after independence, the main thrust of Indian Government centered on meeting the basic needs of India's population which include food, clothing and shelter. With this perspective, the national policy makers looked at various measures to alleviate the rural poor. The process of self governance and planning by empowering the people through Panchayati Raj system although started nearly five decades earlier, but 73rd and 74th amendments in the Constitution of India brought an historic change in the process of decentralisation towards the grass root level and participation of people both in the formulation as well as implementation of the plans. The paper explores how the Constitution 73rd Amendment Act (1992), provided certainty, continuity and strength to the PRI's for the welfare of the weaker sections through Decentralization. Uniform three-tier level of the village, block and district levels, direct elections to all seats and at all levels, indirect elections to chairpersons at intermediate and apex levels. Reservation on rotational basis for SC's ST's in proportion to their population, both for membership as well as Chairpersonships of the PRI's. Not less than one third of the seats and offices reserved for women. The present paper intends to discuss the political participation of weaker sections in panchayat raj institutions in Karnataka in general and in Afjalpur taluk of Gulbarga District in particular as a case study. Finally the paper discusses about the political participation of weaker sections and sought their opinion of their involvement in the process of political, economic development and social justice, with the transfer of the list of Eleventh and the Twelfth Schedule of the Constitution to the rural and urban elected local bodies, and the process of welfare activities for weaker sections through the Panchayat Raj Institutions has been discussed.
\end{abstract}

Keywords: Panchayat Raj Institutions, Political Participation, Weaker Sections.

\section{Introduction:}

Social inequalities existed in the villages and these have continued for centuries. Under these circumstances, soon after Independence the concept of social justice figured in the Indian constitution. Thus the constitution of India made an attempt to provide equal social opportunities for the development of personality of all the people in the society, without any discrimination on the basis of caste, sex or race. However, social inequalities continued for a long time in the Indian society. The reasons may be several. The people from higher social strata had received education, and they controlled and managed land. They took up income earning activities. On the contrary, the lower strata people were denied education, and they were deprived of their right to manage and control land. Thus they were forced to take up low - income earning activities. Particularly in the villages the lower strata people took up supportive works for the people who had taken up agricultural activities, such as Carpentry, Blacksmith, Leather work, and labour.

Due to the above- mentioned reasons the marginalized became the weaker sections of the society. Therefore, after Independence, India was one among the countries which went in for social and economic transformation of the rural population. As a preferred condition, rural development became a definite strategy for the 
improvement of the living conditions of the rural poor. In this direction the Government of India made efforts to solve problems such as poverty, ill health, illiteracy, and backwardness of varied nature prevailing in rural areas, by giving grater attention to the uplift of the rural poor (Shivanna N. 1990) .

Further, the marginalized sections, i.e., SC, ST, and OBC have become an important component in defining of the development policies because of their socio-economic deprivation in the traditional society like India. The political involvement of the upper castes is still more in institutions like Assembly and Parliament. The reservation of seats was $15 \%$ in State Assemblies and Parliament. On the contrary there was no representation from the larger sections of the marginalized castes i.e., from the backwards (Singh S.N. 1996). As a result of this, at present, political participation in India is limited to only a few upper castes. As they manage and control the political system, land pattern. The upper caste people did not mind in formulating and execution of welfare and developmental policies intended for the weaker sections. It can be seen in the failure of several programmes. Among these are community Development Programmes (CDP) and National Extension Programme (NEP). These programmes were implemented in tune with the upper caste people in the rural areas.

\section{Review of Related Literature}

Sinha (2004) in her article, 'Women in Local Self-governance' points out that deep poverty are a social and political phenomenon as much as an economic problem and require political and social change, particularly within the field of power. The quest for equity cannot come about without wider representation of all groups; especially those currently denied access to power, and the presentation of all points of view in the process of decision-making. Revision of the current administrative and political structures, and their rules, is necessary in order to facilitate this broader representation and its translation into political power for those who are currently marginalized.

Singh, Surat"s (2004) article presents the findings of an empirical study of the elected women representatives of the Panchayat raj institutions of Haryana by exploring the extent of their empowerment as a result of the implementation of the 73rd Amendment to the Indian Constitution which made provision for the reservation of one-third share for women in these institutions. It also aims to present some suggestions for making the participation of women effective in these institutions of decentralized rural governance. He concluded with several suggestions, namely, the men"s negative attitude towards women members, attitudinal change among both men and women, education of women, community organizations encouragements ( SHGs, Mahila Mandal, etc.) regular attendance in the meeting, encouragement from family and local community, and media are quite important to change the environment for the women to participate in local governance quite effectively.

Ramanuja Rao. K and Manduva Narasimha Rao (2005) in their case study on Gangadevipally Village in Geesukonda Mandal, Warangal district of Andhra Pradesh depicted and appreciated $100 \%$ participation of women in village administration. They pointed out that the unique feature of this village is that all women leaders have formed a group of committees as parallel watch bodies to the mandatory Gram Panchayati system. They further observes that the political power gave the women leaders of this village a sense of importance and of courses, a lot of responsibility fell on their inexperienced yet accepting shoulders.

Vinod Vyasulu (2003) in his book 'Panchayats, Democracy and Development' reviews the state of affairs in Karnataka, which he says was the harbinger of decentralised rule. The state's experiment with local bodies started in the 1960s; in 1983 a new law was passed that began to be implemented from 1987. The zilla panchayat head was given the status of a minister of state; he had control over the chief secretary of the district (an ias officer). He laments that today the power local bodies possess remains on paper. Local governments actually have no control over the district bureaucracy and this makes pris shaky. The head of the zilla panchayat continues to be an employee of the state government, with the power to merely refer to the state government those decisions the zilla panchayat feels are not in tune with the law. The author also dissects the financial functioning of pris with precision. Not only do Panchayats lack flexibility in deciding the 
heads of expenditure (most funds are 'tied'), they also cannot mobilize resources on their own. In this sphere, too, local bodies depend on the state government and the Centre. 'Tied' funds means funds allotted under specific heads (determined at the 'top') which simply lapse if unused. Thus often, the local bodies become a mere conduit for directing expenditure. Though panchayats have some tax power, very little tax is actually collected, so much are they forced to remain dependent on state governments.

Finally, in the book the author cautions that since decentralisation came to be implemented from above, without there being a real demand for it, it is now necessary to see that people's participation and interest has to be ensured. It goes without saying that if the local governments do function as real units of selfgovernment, then people's endorsement won't be long in coming. But how does one bell that cat called 'political will'?

The dissertation of Bhandare S.A, (2007), entitled 'Finance of Hupari Village Panchayat,' attempted to study the finance of Hupari Village Panchayat. He studied the overall budgetary trends and analyze income and expenditure source of Hupari Village Panchayat. The period of the study was selected from 2000-01 to 200506 for which comparative data is available. The study was based on secondary data gathered from the official records of the Hupari Village Panchayat. The main findings are Hupari Village Panchayat faced deficit for above five years, and it was having a larger volume of a deficit, but better performance in the collection of tax revenue. Finally, author suggested that Village Panchayat could assume a finer role in planning and implementation of economic activities, for doing this Village Panchayat should be given finer power to collect revenue, so that it can work successfully.

Kadam B. J. (2008), in his M.Phil Dissertation 'Village Panchayats and Rural Development,' he studied the Panhala Taluka in Kolhapur District as in all 111 Village Panchayats, out of that $5 \%$ sample based on stratified sampling consisting of both the high and low income Panchayats have been taken. This consists of total six Panchayats divided three into high income and three into a low income group of Panchayats. The highincome Panchayats are Kodoli, Wadi Ratnagiri, Panore and low income Panchayats are Kolik, Pisotri, Salawadi for the period of nine years from 2000-01 to 2008-09. The main objective of the study is to find out the overall budgetary position of the Village Panchayats and examine the growth and composition of revenue and expenditure, to identify the problems and suggest measures. The main findings are above six Panchayats in Panhala Taluka have faced the problems of deficit during the period of the study. He did not find a single Panchayat, which was not in deficit. He lastly, concluded that the role of Village Panchayat has been playing an important role in rural development, but it is not adequate. Inadequate revenue as indicated by deficit, a shortfall of capital receipts and capital expenditure are important. Hence, they have neglected economic development as well as capital expenditure in rural development. It is necessary to pay attention by Panchayats in adequate revenue mobilization as well as on spending for water supply, education, agriculture, environment protection, etc.

Fernands, Aureliono (2008). In his book 'Panchayatantra: Empowering Local Government Through Role Definition,' at the time when the forces of globalization are undermining the democratic capacities of national governments, there is a need to strengthen the grass-root democracy. Globalization has, no doubt, promoted growth, but it is not an inclusive growth. The gap between the rich and the poor, and the rural and urban areas are increasing day by day. It is growingly felt that inclusive growth can promote only by strengthening local governance. The draft of the Eleventh Five Year Plan in India speaks of substantially empowering and using Panchayati Raj institutions as the primary means of delivery of essential services that are critical to inclusive growth. From this perspective, the book under review is a timely contribution. It is an excellent intellectual endeavour to strengthen the role of institutions involved in the process of rural local governance.

The 73rd Constitution Amendment Act (1993) was a great leap forward in the direction of promoting democratic decentralization in India. During the last fifteen years it has symbolically empowered marginalized groups through political representation and quotas. However, the goals of equitable development and enduring social change still remain distant dreams. There are various deficits/constraints in the functioning of 
the PRIs that need to be addressed to achieve the above mentioned goals. Dr. Aureliano's present work is an attempt to highlight the centrality of the epistemic deficit which, according to him, impedes the process of inclusiveness and effective functioning of PRIs. The 'epistemic deficit' includes the 'knowledge deficit' of 'know how' about not only the composition, jurisdiction and powers of institutions; position, powers, functions and duties of personnel but the context in which these institutions and personnel are located and the role they are expected to play. The author seeks to underline the fact that empowerment and participatory democracy is contingent upon information and knowledge dissemination. He attempts at showcasing how even a relatively well developed polity like Goa seeks to go through the motion of development process by exclusion.

The author opines that if India lives in its villages, then the villages are the primary governments. It is here that empowerment should begin through liberal knowledge and information flow. It is forcefully argued that channelizing the energies of people within the Panchayat, the Block and District in creative and emancipatory ways is possible by information and knowledge dissemination. By outlining the roles of institutions and individuals and setting agenda for the future, the book is definitely going to serve as a reference to all those individuals' institutions who are interested in strengthening the Panchayati Raj Institutions in India.

Bhola Nath Ghosh (2008) book titled 'Women in Governance in Tripura' reveals Panchayati system in Tripura has progressed a long way from its traditional to present day structure. Before Tripura merged with the Indian Union in 1949, it was a princely state. There were traditional village level institutions based on traditional customs, which took important decisions in matters pertaining to tribal communities and to dispute among their members. But these institutions could hardly be descried as democratic, depending as they did on the social legitimacy conferred on them by the existing powers structure and social order. Women were denied the right to participate in these village councils. The real breakthrough in democratic local self-government came with the accession to office of the Left Front Government in Tripura. For the first time, elections to panchayats were held through secret ballots and with open participation of political parties. Tripura has a single-tier system of village panchayats till 1978, when the left government brought forward legislation to constitute a two-tier panchayat system. Following the 73 Constitutional Amendment of 1992, Tripura enacted the Tripura Panchayat Act, 1993, and introduced a three tier structure. This book examines the role of women members of Gram Panchayats in Tripura since 1993, when their representation in Panchayats increased due to reservation of seats as a result of the 73rd Constitutional Amendment. This book analyzes their socioeconomic and political background as well as their level of awareness about socio-political situation and their exposure to outside world. It also investigates whether their election to panchayat bodies has made any significant change in the status of women in rural areas. Further it also discusses the factors that motivated women members to plunge into politics and fight panchayat elections.

In this book the study carried out by the author indicated that the participation of women in panchayat decision-making process in term of attendance, opinion expressed and issue raised in the PR meetings, confidence repose and satisfaction for effective participation was noteworthy. They were not mere the mute spectators or ornaments in the decision-making process, rather a likely force to reckon with. They maintained contacts with villagers took villagers demand into cognizance and tried to deliver whatever was possible for them. The author also found that most of women members had no previous political exposure and experience. Most of them did not hold any type of political post and even they were not primary members of any parties. But at present women have joined various socio-economic and political activities. It is also true that almost everywhere they are caught in the dilemma of role adjustment. Bias against women is likely to slow down only gradually.

In this book the author observed that women's participation in the Gram Panchayats has substantially increased but mere reservation would not solve the problem unless women members are given due powers to function effectively. In order to empower women's he advocated all women panchayats members should be trained by suitable resource persons dealing with self-government activities. The training should include the philosophy as well as administration of panchayati raj the political and social essence of democracy and the attitude towards the people. The training courses should address such general works and programmes which 
are specific to women's welfare. The training programmes should be carried out in small groups so that there is sufficient interaction between the trainer and the trainees. The author also acknowledged the fact that newly elected representatives should not be expected to acquire overnight the capabilities needed in different fields. Till they achieve such competence, they should be guided and assisted by elderly and experienced panchayat personals.

The author wants the women's dual responsibilities to be appreciated and shares by male members. He also acknowledged that the women panchayat members still face male dominance not in family but also in the official work. The author noticed that women may have some exclusive problems such as maternity and childcare but all development issues almost equally concern both men and women. Their interest cannot be isolated from the economic, social and political interest of other groups. In this book the author observed that women members unanimously asserted that they were not in favour of exclusive women's issues but rather they tried to work for collective interest of village also. Overall this book is a commendable effort by the author to asses' women's participation in Panchayati Raj Institution in Tripura. This work has revealed a lot of facts relating to the issue of political empowerment of women in the state. The distinctive approach and methodology adopted by the author have enabled him to capture the socio-economic profile of the women members in Tripura. His study also shows how energetic attempts of members made the panchayati raj institution in rural areas vibrant and lively.

\section{Committees Appointed from Time to Time}

After the Community Development Programme was launched in 1952, it was realized that without an agency at the village level, which could represent the entire community, assume responsibility and provide the necessary leadership for implementing development programmes, real progress in rural development could not take place. It was against this background that a Committee headed by Balwant Rai G. Mehta was appointed in 1957 to make recommendations for revitalization for the Panchayati Raj system define its role in the development process. The report of the Committee recommended that public participation in community works should be organized through statutory representative bodies. Community Development can be real only when the community exercises necessary powers through its chosen representatives. Therefore, it recommended the establishments of statutory elected local bodies.

The report of the Committee was influential in creating a three-tier Panchayati Raj structure with District Panchayat at the top and Grama Panchayat at the bottom. The intermediate tier was co-terminus with Community Development Blocks. Most of the States amended their laws to conform to the recommendations of the committee. However, the Panchayat raj institutions could not function well as elections were either not held or were frequently postponed or they were denied funds or in most of the cases superceded. The Ashok Mehta Committee Report in 1978 was influential in bringing about a shift in emphasis between the first and second degeneration of panchayats from development per se to local Government in its full meaning. Originally, panchayats found a place only in the Directive Principles of State Policy. The $73^{\text {rd }}$ and $74^{\text {th }}$ Constitutional Amendments revitalized the Panchayats and Urban Bodies by giving them Constitutional status, providing for regular elections and reserving $1 / 3$ seats for women and introducing representation for marginalized groups.

\section{$7^{\text {rd }}$ Constitutional Amendment Act}

To provide the constitutional support to the Panchayati raj institutions, a Constitutional Amendment Bill was introduced in 1989 by Late Rajiv Gandhi the then P.M., with an intention of transferring power to the people. It relates to part IX of the constitution. This bill was passed by the Lok Sabha on the $10^{\text {th }}$ August 1989 . However it failed in Rajya Sabha and could not become the part of the constitution. After the defeat of both the bills, another bill that is $73^{\text {rd }}$ constitution amendment Bill was introduced in the Lock sabha. The attempt extending the constitutional benefits to the panchayat raj institutions, thoroughly the $64^{\text {th }}$ Constitutional Amendment Act of 1988 and $74^{\text {th }}$ Amendment Bill of 1990 did not succeed. Another attempt was made by introducing the Constitutional Amendment Bill on $16^{\text {th }}$ September 1991. After the series of discussions in the 
parliament, the matter was referred to joint select committee of parliament for detailed examination. Accordingly joint committee presented its report to parliament in July 1992. The Lok Sabha finally passed the bill on December $22^{\text {nd }} 1992$ and the Raja Sabha on December $23^{\text {rd }} 1992$. The President of India accorded this asset on April 20 th 1993 . Finally the $73^{\text {rd }}$ constitutional amendment act of 1992 came into effect on April $24^{\text {th }}$ 1993 (Panchayat Raj at a Glance: 1964).

There shall be three tiers of Panchayats at the village, intermediate and district levels. So, only those states having population not exceeding 20 lakhs have the discretion not to constitute the panchayats at the intermediate level. Under Article 243 the president can make special dispensation for Union Territories.

Direct elections: All seats in a panchayats at every level are to be filled by direct elections from territorial constituencies demarcated for this purpose, with the ratio between the population of such constituency and the number of such constituency and the number of seats allotted to it being the same throughout the Panchayat area. Reservation of seats: There shall be reservation of seats at every level for SC/ STs in proportion to their population in a given Panchayat area and for women to the extent of not less than one- third of the total number of seats. Likewise, the office of the Chairpersons in the Panchayats at each level shall be reserved for women, to the extent of not less than one-third of the total numbers in the office of Chairpersons of Panchayats. In addition, the legislature of any state can make provision for reservation of seats in any panchayats at any level in favour of the backward classes.

Five year term: The term of office of panchayat at every level shall be for five years and if dissolved earlier or on expiry of the term, elections must be completed within six months from the date of dissolution or expiry.

Finance Commission: By 24th April 1993, that is, the coming into the effect the constitutional (73rd Amendment) Act, 1992 and thereafter at the expiration of every fifth year, a finance commission shall be constituted in every fifth year. A finance commission shall be constituted in every state to go into the governing principles of the distribution and revolution of financial resources between the state and the panchayats at every level and the measures to improve the financial position of the panchayats.

State election commission: The direction and control of the preparation of electoral rolls and the conduct of all elections in the panchayats shall be vested in a state election commission, to be constituted by the state concerned.

Eleventh Schedule: Finally, the XI Schedule comprising 29 items has been added to the Constitution which ought to provide an effective role to the PRIs in the planning and implementation of works of local significance. Activities ranging like drinking water, agriculture, land and water conservation to communications, poverty alleviation programmes, family welfare, education, libraries and cultural activities, maintenance of community as sets etc.

\section{Karnataka Panchayat Raj Act 1993-Salient Features}

The 1993 Act establishes a three-tier Panchayat raj system in the state with elected bodies at Gram, Taluka, and District level for greater participation of the people and for more effective implementation of Rural Development Programmes. The three tiers of the Panchayat Raj System are:

1) Gram Panchayat/Village Panchayat.

2) Taluka Panchayat.

3) Zilla Panchayat.

As apart from the creation of three-tier panchayat system in the state based on population as per published data of census, the features of 1993 Act are as follows (The Karnataka Panchayati Raj Act: 1993).

1. The act facilities the constitution of grama sabha in each village. 
2. It provides for reservation of seats in favour of SCs and STs in proportion of their population and subjected to minimum of 15 and $3 \%$ respectively at all levels.

3. The Act provides for reservation of $1 / 3$ of seats to women at all levels.

4. It also provides for reservation of $1 / 3$ of seats to persons belonging to Backward Classes.

5. The Act also provides for reservation of $1 / 3$ of seats in each category (SCs, STs, and Backward Classes and General) at all levels for women. The seats reserved shall be allotted by rotation to different constituencies in panchayat area.

6. The office of the Chairperson and Deputy Chairpersons are also reserved at all levels for the persons belonging to SCs, STs and Backwards Classes and Women.

7. The Act envisages the constitution of state election commission, the finance commission and district planning committee. The finance committee is to recommend periodically the policy on finance to Panchayat Raj Institutions.

8. The new law stipulates that the elections to Gram Panchayat are to be conducted on non-party basis. This is intended to minimize the local conflicts during election time. However, participation of political parties has been allowed for upper level Panchayats.

9. The new Act substantially increases the power of State governments to supervise and control Panchayat Raj Institutions. The Secretary of Panchayat Raj Department and the Divisional Commissioner are empowered accordingly for this purpose. They are entitled to issue instructions, conduct enquiry, and call for proceedings of Zilla Panchayat and performance of Panchayat Raj Institutions. The government is also authorized to add or delete any programme or scheme in the functions of Panchayat Raj Institutions.

10. All the Adhyakshas of Taluka Panchayats can be members of Zilla Panchayats. All the MLAs, MLCs, and MPs can be Members of Zilla Panchayats and Taluka Panchayats.

11. As regards to finance, every Gram Panchayat will receive annual grant of rupees one lakh towards development activities.

12. The proceeds of heavy cash levy, on land revenue and surcharge on stamp duty will be passed on to Gram Panchayats and Taluka Panchayats. The Panchayat Raj Institutions will receive resources from State Government also.

\section{Objectives and Methodology}

The present paper intends to analyze the involvement of weaker sections representatives in the institutions of Panchayat Raj in Gulbarga and Afjalpur Taluk of Gulbarga District. It also intends to assess the awareness, commitment, ability and problems of weaker sections representatives in the process of implementing the welfare policies for SC, ST and OBC, historical descriptive and analytical methods have been employed in the present study.

To examine the status of weaker sections in village Panchayats of Gulbarga and Afjalpur Taluks in Gulbarga District and to compare the status of weaker section's representatives with the representatives of other castes in Panchayat Raj Institutions of Gulbarga District. To identify the education level of weaker sections representatives in Panchayat Raj Institutions of Gulbarga District. Awareness towards the working of Panchayat Raj institutions, suggest policy implementations for the effective involvement of weaker section and to implement welfare policies for weaker sections through Panchayat Raj institutions. 


\section{Political Participation of Weaker Sections}

It is widely believed that the analysis of age, education, Caste, family structure, occupation, income, land holding, party affiliation, etc., are important in determining the nature of leadership. The data relating to socioeconomic background of elected respondents of Panchayati Raj institutions were collected in the \% study to get an insight into the emerging pattern of rural leadership in the Afjalpur Taluk of Gulbarga District.

The socio-economic conditions play an important role in characterizing the social life and behaviour of an individual. The socio-economic status of an individual affects the patterns of interaction in the society. It is, therefore, essential to analyse the socio-economic background of the relationship between the leader and the environment. In a developing society like ours where forces of caste and kinship influence the social life and acute disparity in the standard of living and sub culture among various groups and regions are existing, a study of the socio-economic conditions of SC, ST and OBCs respondents would help reveal sociologically significant dimensions (Singhi, N.K. 1974).

The socio-economic, educational and political background of the leaders would also enable us to anticipate as to what they are capable of doing, what we should expect from them and how well they are equipped to discharge the responsibilities developed upon them by the electorate (Sashilata Puri 1978). Knowledge of socio-economic background of a community is an indispensable prerequisite, for the understanding of the thought or behaviors of its members. This holds good for all human communities, and more so in the case of $\mathrm{SC} / \mathrm{ST}$ and $\mathrm{OBC}$ communities, which are intrinsically more traditional in their structure.

Table No. 1. Distribution of Respondents by Nature of Members.

\begin{tabular}{|l|l|l|l|}
\hline S.No. & Institution & Frequency & $\%$ \\
\hline 1 & VP & 44 & 58.67 \\
\hline 2 & TP & 23 & 30.67 \\
\hline 3 & ZP & 8 & 10.67 \\
\hline 4 & Total & 75 & 100.00 \\
\hline
\end{tabular}

Table No. 1 is to discuss the nature of members in the study area. It is evident from the table that there are three types of members, i.e (1). Village Panchayat members are 44 constituting $58.67 \%$, Taluk Panchayat members are 23 constituting $30.67 \%$ and Zilla panchayat members are 8 constituting $10.67 \%$.

Table No. 2. Distribution of Respondents by Position in PRIs

\begin{tabular}{|l|l|l|l|}
\hline S.No & Position & Frequency & $\%$ \\
\hline 1 & Presidents & 10 & 13.33 \\
\hline 2 & $\begin{array}{l}\text { Vice } \\
\text { Presidents }\end{array}$ & 17 & 22.67 \\
\hline 3 & Members & 48 & 64.00 \\
\hline 4 & Total & 75 & 100.00 \\
\hline
\end{tabular}

Table No. 2 is intended to discuss the position of respondents in the Institutions of PRIs Afzalpoor Taluk. The response and the study area have been grouped into three categories that is 1 . Respondents 10 constitute $13.33 \%$, vice - presidents 17 constituting $22.67 \%$ and members 48 constituting $64.09 \%$. 
Table No. 3. Distribution of Respondents by Sex

\begin{tabular}{|l|l|l|l|}
\hline S.No & Sex & Frequency & $\%$ \\
\hline 1 & Male & 49 & 65.33 \\
\hline 2 & Female & 26 & 34.67 \\
\hline 3 & Total & 75 & 100.00 \\
\hline
\end{tabular}

Table No. 3 discusses the sex wise distribution of respondents in the study area. It is evident from the table that out of the total 75 respondents, the highest number 49 constituting $65.33 \%$ are male and 10 respondents constituting $13.33 \%$ are female.

Table No. 4. Caste - Wise Distribution of Respondents

\begin{tabular}{|l|l|l|l|}
\hline $\begin{array}{l}\text { SI. } \\
\text { No }\end{array}$ & Caste & Frequency & $\%$ \\
\hline 1 & SC & 25 & 33.33 \\
\hline 2 & ST & 10 & 13.33 \\
\hline 3 & OBC & 40 & 53.33 \\
\hline 4 & Total & 75 & 100.00 \\
\hline
\end{tabular}

Table No 4. is intended to discuss the cast wise distribution of the respondents in the study area. The table shows that out of the total sample 75, respondents belonging to SC are 25 constituting $33.33 \%$, STs are 10 constituting $13.33 \%$ and $\mathrm{OBCs}$ are 40 constituting $53.33 \%$.

Table No. 5. Distribution of Respondents by Age

\begin{tabular}{|l|l|l|l|}
\hline S.No & Age & Frequency & $\%$ \\
\hline 1 & $18-25$ & 22 & 29.33 \\
\hline 2 & $26-35$ & 34 & 45.33 \\
\hline 3 & $36-45$ & 8 & 10.67 \\
\hline 4 & $46 \&$ Above & 11 & 14.67 \\
\hline 5 & Total & 75 & 100 \\
\hline
\end{tabular}

Table N0. 5 is intended to analyse the distribution of respondents by age. It is observed from the table that the age group of the respondents has been grouped into 4 categories. Among these the highest number of respondents 34 constituting $45.33 \%$ are from the age group of 26 - 35, followed by 22 respondents constituting $29.33 \%$ belonging to the age group of $18-25$. Further the table shows that the lowest number 8 respondents constituting $10.67 \%$ are from the age group of $36-45$.

Table No. 6. Distribution of Respondents by Religion

\begin{tabular}{|l|l|l|l|}
\hline S.No & Religion & Frequency & $\%$ \\
\hline 1 & Hindu & 53 & 70.67 \\
\hline
\end{tabular}




\begin{tabular}{|l|l|l|l|}
2 & Buddhism & 15 & 20.00 \\
\hline 3 & Muslims & 4 & 5.33 \\
\hline 4 & Others & 3 & 4.00 \\
\hline 5 & Total & 75 & 100.00 \\
\hline
\end{tabular}

Table No.6 is to analyse the Distribution of Respondents By Religion. The table shows that out of the sample 75 respondents, the highest number 53 respondents constituting $70.67 \%$ are Hindus, followed by 15 respondents constituting $20 \%$ are Buddhists; these Buddhists are converted from a particular caste among the SC. In the study area there are 4 respondents constituting $5.33 \%$ belonging to Muslim OBCs, and 3 respondents constituting 4.00 per cent belonging to other religions.

Table No. 7. Distribution of Opinion by Caste About the Objectives of Panchayat Raj Institutions

\begin{tabular}{|l|l|l|l|l|l|l|l|l|l|}
\hline S.No. & Opinion & SC & $\%$ & ST & $\%$ & OBC & $\%$ & Total & $\%$ \\
\hline 1 & Yes & 19 & 76 & 5 & 38.46 & 10 & 27.03 & 34 & 45.33 \\
\hline 2 & No & 6 & 24 & 8 & 61.54 & 27 & 72.97 & 41 & 54.67 \\
\hline 3 & Total & 25 & 100 & 13 & 100.00 & 37 & 100.00 & 75 & 100.00 \\
\hline
\end{tabular}

Table No 7. Reveals that the caste wise distribution of respondent's opinion about the objectives of Panchayat Raj institutions. The table reveals that out of the total 75 respondents, the highest number of respondents across the castes does not know about the objectives of Panchayat Raj institutions. The caste wise distribution of opinion reveals that there are 25 respondents from SC. Among these the highest number $76 \%$ of respondents are aware of the objectives of Panchayat Raj institutions. Where as only $24 \%$ of respondents do not know the objectives of Panchayat Raj institutions.

The respondents belonging to STs opined the different opinion than SC respondents. The highest number $61.54 \%$ respondents out of 10 do not know the objectives of Panchayat Raj institutions and where as 38.46\% of respondents are aware of the objectives of Panchayat raj Institutions.

So for as concern of the $\mathrm{OBC}$ respondents, out of the total 40 , the highest number 30 respondents do not know the objectives of Panchayat Raj Institutions. The over all observation of the table is that majority of SC respondents are aware of the objectives of Panchayat Raj Institutions. And on the other hand majority of respondents from STs and OBC are not aware of the objectives of Panchayat Raj Institutions.

Table No. 8. Distribution of Respondent's Opinion by Education about the Objectives of Panchayat Raj Institutions

\begin{tabular}{|l|l|l|l|l|l|l|l|l|l|l|}
\hline Opinion & Illiterates & \% & $\begin{array}{l}\text { Up to } \\
\text { 10th }\end{array}$ & \% & PUC & \% & Degree & \% & Total & $\%$ \\
\hline Yes & 9 & 37.5 & 5 & 17.24 & 3 & 20 & 7 & 100 & 24 & 32 \\
\hline No & 15 & 62.5 & 24 & 82.76 & 12 & 80 & & & 51 & 68 \\
\hline Total & 24 & 100 & 29 & 100.00 & 15 & 100 & 7 & 100 & 75 & 100 \\
\hline
\end{tabular}


Table No. 8. Shows that the education wise distribution of representative's opinion about the objectives of Panchayat Raj institutions. The table reveals that out of the total respondents belonging to illiterates, the highest number $62.5 \%$ of respondents do not known the objectives of Panchayat Raj Institutions, and 37.5\% respondents are awarded of the objectives of Panchayat Raj Institutions. Among the total, 29 respondents who are studied up to SSLC, the highest number $82.76 \%$ are not known about the objectives of Panchayat Raj Institutions, only $17.24 \%$ are known. The respondents who have studied up to PUC are 15 in total, among these the highest number $80 \%$ respondents does known the objectives of Panchayat Raj Institutions. It is evident from the table that the respondents who are studies up to degree are 7 in total and these respondents have understood the objectives of Panchayat Raj Institutions.

The overall observation of the table is that most of the respondents with lower educational level such as illiterates, studied up to10 th and pre University education (PUC) are not understood the objectives of Panchayat Raj Institutions in the study area. On the other hand the graduation as the level of education of the respondents are fully understood the objectives of Panchayat Raj Institutions.

Table No. 9. Distribution of Opinion by Caste Towards the awareness of $73^{\text {rd }}$ Constitutional Amendment Act

\begin{tabular}{|l|l|l|l|l|l|l|l|l|l|}
\hline S.No & Opinion & SC & $\%$ & ST & $\%$ & OBC & $\%$ & Total & $\%$ \\
\hline 1 & Yes & 18 & 72 & 6 & 60 & 10 & 25 & 34 & 45.33 \\
\hline 2 & No & 7 & 28 & 4 & 40 & 30 & 75 & 41 & 54.67 \\
\hline 3 & Total & 25 & 100 & 10 & 100 & 40 & 100 & 75 & 100.00 \\
\hline
\end{tabular}

Table No. 9 discusses the caste wise distribution of respondents towards the awareness of $73^{\text {rd }}$ Constitutional Amendment Act. The respondents in Panchayat Raj Institutions are supposed to be understood the provisions of $73^{\text {rd }}$ Amendment Act. Because, the radical changes have taken place in the institutions of Panchayat Raj in India by $73^{\text {rd }}$ Amendment Act. The table reveals that the respondents the highest number $72 \%$ of respondents belonging to SC are aware of $73^{\text {rd }}$ Act. The respondents belonging to STs have opinioned that the highest number $60 \%$ of respondents are not aware of $73^{\text {rd }}$ Act and only $40 \%$ of respondents are aware. So for as concern of the respondents belonging to $O B C^{\prime} s$, the highest number $75 \%$ of respondents are not aware of $73^{\text {rd }}$ Act and only $25 \%$ of respondents are aware.

The findings of the table are that the most of respondents belonging to SCS and STs are aware of $73^{\text {rd }}$ Act. And the majority of respondents from ST, and OBC, are not aware of $73^{\text {rd }}$ Act. Therefore, it is viewed that SC \& ST respondents has consciousness towards the working of Panchayat Raj Institutions in the study area.

Table No. 10. Distribution of Opinion by Education Towards the Awareness of $73^{\text {rd }}$ Constitutional Amendment Act

\begin{tabular}{|l|l|l|l|l|l|l|l|}
\hline S.No & Education & Yes & $\%$ & No & $\%$ & Total & $\%$ \\
\hline 1 & Illiterates & 7 & 15.22 & 15 & 51.72 & 22 & 29.33 \\
\hline 2 & Up to10th & 23 & 50.00 & 9 & 31.03 & 32 & 42.67 \\
\hline 3 & PUC & 9 & 19.57 & 4 & 13.79 & 13 & 17.33 \\
\hline 4 & Degree & 7 & 15.22 & 1 & 3.45 & 8 & 10.67 \\
\hline 5 & Total & 46 & 100.00 & 29 & 100.00 & 75 & 100.00 \\
\hline
\end{tabular}


Table No. 10 Reveals the education wise distribution of respondents towards the awareness of $73^{\text {rd }}$ amendment Act. It is evident from the table that the highest number $51.72 \%$ of respondents from illiterates are not aware of $73^{\text {rd }}$ Act. And the highest number $50.00 \%, 19.57 \%$ and $15.22 \%$ of respondents from $10^{\text {th }}$, PUC, and Degree as education level respectively are aware of $73^{\text {rd }}$ Constitutional Amendment Act.

The findings of the table are that the most of illiterate respondents are working in Panchayat Raj Institutions without understanding the provisions of $73^{\text {rd }}$ Act. The most important finding of the table is that the respondents with minimum level of education and above are working in Panchayat Raj Institutions with the awareness of $73^{\text {rd }}$ constitutional provisions.

Table No. 11. Education - Wise Distribution of Respondent's Opinion towards the Accuracy of the Existing Reservation Provisions in Panchayat Raj Institutions

\begin{tabular}{|l|l|l|l|l|l|l|l|}
\hline S.No & Education & Yes & $\%$ & No & $\%$ & Total & $\%$ \\
\hline 1 & Illiterates & 17 & 58.62 & 7 & 26.92 & 24 & 32 \\
\hline 2 & UP To 10 th & 10 & 34.48 & 22 & 84.62 & 32 & 42.67 \\
\hline 3 & PUC & 2 & 6.90 & 12 & 46.15 & 14 & 18.67 \\
\hline 4 & Degree & & 0.00 & 5 & 19.23 & 5 & 6.67 \\
\hline 5 & Total & 29 & 100.00 & 26 & 100.00 & 75 & 100 \\
\hline
\end{tabular}

Table No. 11 Discusses the education wise distribution of respondent's opinion towards the adequacy of the existing reservation provisions in Panchayat Raj Institutions. The table shows that the highest number 58.62\% of respondents from illiterate opined that the existing reservation provisions are adequate. The majority of respondents i.e. $84.62 \%$, who have studied up to $10^{\text {th }}$ opined that the existing reservation provision in Panchayat Raj Institutions are not adequate and only $34.48 \%$ have satisfied with the existing provisions. The majority of respondents who studied upto PUC and degree respectively $46.15 \%$ and $19.23 \%$ are opined that the existing reservation provision are not sufficient in the Panchayat Raj Institutions. The overall observation of the table is that the illiterate respondents in Panchayat Raj Institutions have not understood the reservation provisions and the respondents educational level as $10^{\text {th }}$, PUC and Degree have understood the reservation provisions and they want to increase number of seats for SC,ST and OBC in Panchayat Raj Institutions.

Table No. 12. Caste - Wise Distribution of Respondent's Opinion towards Specific Earmark of Allocations and Expenditure for the Welfare of SC, ST, and OBC in Panchayat Raj Institutions

\begin{tabular}{|l|l|l|l|l|l|l|l|l|l|}
\hline S.No & Opinion & SC & $\%$ & ST & $\%$ & OBC & $\%$ & Total & $\%$ \\
\hline 1 & Yes & 19 & 76 & 7 & 70 & 30 & 75 & 56 & 74.67 \\
\hline 2 & No & 6 & 24 & 3 & 30 & 10 & 25 & 19 & 25.33 \\
\hline 3 & Total & 25 & 100 & 10 & 100 & 40 & 100 & 75 & 100.00 \\
\hline
\end{tabular}

Table No. 12. Reveals that the caste wise distribution of respondent's opinion towards specific earmark of allocations and expenditure for the welfare of SC, ST, and OBC in Panchayat Raj Institutions. It is evident from the table that the majority $76 \%$ of respondents belonging to SCs wanted a specific earmark of allocations and expenditure for the welfare of SC and STs in the institutions of Panchayat Raj, and 24\% of respondents opined that their should not be a special earmark for SC and STs in Panchayat Raj Institutions. Respondents belonging to STs opined that the highest number70\% wanted a special earmark and $30 \%$ does not want a special earmark of allocations and expenditure for the welfare of SC and STs. The highest number $75 \%$ 
respondents belonging to $\mathrm{OBC}$ wanted a special allocations and expenditure where as $25 \%$ are not in favor of special earmark for the welfare of SC and STs in Panchayat Raj Institutions.

The over all observation of the table is that the majority of respondents belonging to weaker sections wanted a special allocations and expenditure for the welfare of SC ST and OBC's in Panchayat Raj Institutions.

Table No. 13. Distribution of Opinion by Caste towards Their Reaction if The Funds Intended for Weaker Sections is not implemented by Panchayat Raj Institutions

\begin{tabular}{|l|l|l|l|l|l|l|l|l|l|}
\hline S.No & Opinion & SC & $\%$ & ST & $\%$ & OBC & $\%$ & Total & $\%$ \\
\hline 1 & Yes & 18 & 72 & 8 & 80 & 25 & 62.5 & 56 & 74.67 \\
\hline 2 & No & 7 & 28 & 2 & 20 & 15 & 37.5 & 19 & 25.33 \\
\hline 3 & Total & 25 & 100 & 10 & 100 & 40 & 100 & 75 & 100.00 \\
\hline
\end{tabular}

Table No. 13. reveals that caste wise distribution of representative's opinion towards their reaction if the funds intended for weaker sections are not implemented by Panchayat Raj Institutions. The table shows that $72 \%$ of respondents belonging to SC expressed that they will keep quite and $28 \%$ opined that they protest in different forms in case the funds from Central and State Governments intended for the welfare of these sections are not utilized by Panchayat Raj Institutions. The respondents belonging to STs, the highest number $80 \%$ of respondents opined that they will keep quite and only $20 \%$ of respondents will protest in various forms. The respondents belonging to $\mathrm{OBC}$ 's, the highest number $62.5 \%$ of respondents will keep quite and $137.5 \%$ of respondents opined that they will protest in different forms in case funds intended for the welfare of weaker sections by Centre or State governments are not implemented.

The overall observation of the table is that the majority of respondents across the castes in Panchayat Raj Institutions are not committed for the utilization of funds given by Central and State Governments for the welfare of weaker sections.

\section{Conclusion}

Social inequalities existed in the villages and these have continued for centuries. Under these circumstances, soon after Independence the concept of social justice figured in the Indian constitution. Thus the constitution of India made an attempt to provide equal social opportunities for the development of personality of all the people in the society, without any discrimination on the basis of caste, sex or race. Therefore, after Independence, India was one among the countries which went in for social and economic transformation of the rural population. As a preferred condition, rural development became a definite strategy for the improvement of the living conditions of the rural poor. In this direction the Government of India made efforts to solve problems such as poverty, ill health, illiteracy, and backwardness of varied nature prevailing in rural areas, by giving grater attention to the uplift of the rural poor. By this study we came to know that the representatives belonging to weaker sections are able to implement welfare policies for the development of SC, ST and OBC in the study area. Due to the illiteracy and ignorance of weaker section's representatives, several welfare policies intended for the welfare of SC's, ST's and OBC's are not implementing properly in the institutions of Panchayati Raj and suggest for effective implementation of these policies for the welfare of weaker sections and bring them to the main stream as well as equal opportunity as stipulated in the Indian Constitution.

\section{References:}

1. Aziz, A. (2000): "Democratic, Decentralization - Experience of Karnataka". 
2. Bhandare S.A. (2007), "Finance of Hupari Village Panchayat," M.Phil Dissertation submitted to Shivaji University, Kolhapur.

3. Bhola Nath Ghosh (2008). 'Women in Governance in Tripura' Concept Publishing Company, New Delhi, 2008

4. Buch, N., Jain, U. and Chaudhary, S.N. (1999): Women in Panchayati Raj in Madhya Pradesh, (Mimeo) Bhopal: Mahila Chetna Manch.

5. Fernands, Aureliono (2008). 'Panchayatantra: Empowering Local Government Through Role Definition,' University Book House, Pvt. Ltd., Jaipur.

6. Hiremath, Ujwala, May, 1997, Women in Grassroot Politics, Vol. 44, No. 2, Social Welfare, p. 13.

7. Kadam B. J. (2008), "Village Panchayats and Rural Development: A Case Study of Village Panchayats in Panhala Taluka of Kolhapur District," M.Phil Dissertation Submitted to Shivaji University, Kolhapur.

8. Lele, M.K. (2001): "Local Government: Conflict of Interests and Issues of Legitimization", Economic and Political Weekly, Vol. XXXVI, No. 51, Dec. 22-28.

9. Maheshwari S.R. (1988). Local Government in India Laskhminarayana Aggrawal, Agra, 1988, p. 61.

10. Nagendra Ambedkar, New Panchayat Raj at work, ABD Publishers, Jaipur, India, 2000.

11. Pai, Sudha, May 2, 1998, 'Pradhanis in New Panchayats' Field Notes From Meerut District, Economic and Political weekly.

12. Panchayat Raj at a Glance (as on 31st March, 1964), New Delhi, 1965.

13. Ram Reddy. G. (1982), "Panchayat Raj and Rural Development in Andhra Pradesh, India" in Norman T. Uphoff, Rural Development and Local Organization in Asia, Macmillan India, Ltd., Delhi, p. 78.

14. Ramanuja Rao. K and Manduva Narasimha Rao (2005). "Gangadevipally Village: All Round Participation in Village Administration" Kurukshetra, (Jou), Vol.53, No.6, April 2005, PP.31-34.

15. Sashilata Puri (1978), "Legislative Elite in an Indian State: A Case Study of Rajasthan", New Delhi: publications, p. 31.

16. Shivanna N. (1990) "Panchayati raj Reforms and rural Devaelopment", Usha Prakashan Mandir, Allahabad, p.2.

17. Singh, S.N. (1996). "Reservation Policy for Backward Classes", Rawat Publications, Jaipur, New Delhi.

18. Singh, Surat (2004). Empowerment of Women Representatives in Panchayat Raj- A Profile from Haryana, Kurukshetra, August-2004, Vol.52. No.10, pp.130-139.

19. Singhi, N.K. (1974) "Bureaucracy, Positions and Participation", New Delhi: Abhinav Publications, P. 55.

20. Sinha, Archana (2004). Women in Local Self-Governance, Kurukshetra, April 2001, Vol.52, No.10, 11-15.

21. Sukla Deb, Kanoongo, January-March, 1996, Panchayat Raj and Emerging Women Leadership, Vol. 46, Social Welfare, p. 86.

22. Sweeta Mishra. 1994. "Democratic Decentralization in India", Mittal Publications, New Delhi, 1994, p. 67.

23. Vinod Vyasulu (2003). Panchayats, Democracy and Development, Rawat Publications, New Delhi. 